ested in advancing his ideas, not himself.

James Malloy, a former student, colleague, and friend of Richard Cottam's poignantly summed up his life and the meaning of his death:

He saw his life among us of the academy as a vocation to be measured by the standards of honor and integrity, not success and self advancement. He lived for his vocation and thereby kept faith with himself, generations of students, and the countless audiences he reached with his books and public speeches. He was a man of the academy and a public man. He loved the world. He sought to ease its pain and point toward the resolution of its tragic conflicts. He gave the best of his mind to his students; gave fully of his heart and spirit as well. In doing so he conveyed to his students, colleagues, and friends the compassionate respect that makes a life in common possible. He won our respect, our admiration, our love. He cannot be replaced.

Martha Cottam

Washington State University

Richard K. Herrman

Ohio State University

Bert A. Rockman

University of Pittsburgh

\section{Francesco Kjellberg}

It was with great surprise and deep sorrow that colleagues and friends of Francesco Kjellberg received the news of his death on October 5 of this year. Though it was well-known that Franco recently had confronted cancer, it was generally believed that he had overcome the worst of the illness. He was indeed proclaimed at the end of his treatment over a year ago to represent a highly successful example of how far medicine in the area had come. When it became clear earlier this year that the treatments had in fact not been completely successful, and that he had to begin with a completely new regimen, he chose to confront the situation largely on his own. He continued with his teaching and research, and participated to the full on all fronts at the IPSA World Congress in Seoul. Tough and brave man that he was, he kept the real state of his sickness to himself right up to the very last. He was admitted to the hospital on a Friday afternoon, and passed away on Sunday evening.

Franco Kjellberg was among the youngest of an exceptional generation of Norwegian social scientists who distinguished themselves both nationally and internationally: Stein Rokkan, Wilhelm Aubert, Johan Galtung, Christian Bay-all equally at home with several disciplines, languages, and organizational affiliations. Though originally trained as a sociologist, with a highly creative and insightful doctorate on communal politics in Sardinia, he quickly established himself as Norway's leading political scientist within the area of local government. Having at an early age held all of the normal administrative positions in the Department of Political Science, University of Oslo, he was soon recruited to numerous national commissions and research bodies. He served the original Norwegian Research Council for Science and the Humanities (NAVF) in numerous capacities, and was chairman of several institutional boards, including the Norwegian Institute of Applied Social Research (INAS) and the Centre for Environment and Development at the University of Oslo (SUM). He was also Chair of the Governmental Commission on Income Policy in 1987-89, and served on several other highlevel legislative and administrative commissions.

As head of the doctoral program in the Department of Political Science between 1981 and 1985, and through his own graduate seminar on municipal governance over the entire span of his teaching career, Franco Kjellberg exerted an enormous influence on several generations of researchers and public servants. No teacher of political science in Norway has counselled more graduate theses and dissertations than Franco, and his network of exstudents reads as a Who's Who in social research and public service. Like everything else in life, he took his responsibilities as teacher and graduate advisor very seriously, never cutting corners and never trying to shirk what he perceived as an essential function for the discipline. On the international scene, it was first and foremost IPSA that at- tracted Franco's attention and that, over the years, received so much from him. Having been secretary of the Norwegian Political Science Association already in 1967 , he continued for the rest of his life to devote a large part of his organizational and administrative talent to a profession he truly admired. His image of the discipline was thoroughly professional. With numerous contacts as visiting professor at leading political science institutions around the world, he brought to his work in IPSA an exceptional understanding of differing scientific cultures and standards. He was a bridge-builder and mediator par excellence, traits that not only characterised his period as secretary general of IPSA between 1988 and 1994, but which also coloured his growing involvement in the politics of divided societies. Having been born into a dualculture family of Italian-Norwegian origin, Franco understood the tensions of cultural conflict at first hand and gradually developed his insights into a truly "internationalist" perspective.

In addition to his period as secretary general, Franco served IPSA in numerous other capacities. He was, for example, secretary of the research cornmittee on the "Comparative Study of Local Government and Politics" between 1976-79, member of the executive committee between 1979 and 1985, and program chair of the XIII World Congress in Paris in 1985. During his period as secretary general, the organization made considerable strides both financially and organizationally. He was a demanding secretary general, both of himself and of others. But his standards were always those which he believed to be in the best interests of the discipline. His period as secretary general, with Lise Fog in assistance, will be remembered as one of professionalism and a focused attention on the internationalisation of IPSA. His contacts and efforts on behalf of third-world organizations and colleagues will be particularly remembered.

At his death, Franco was also a member of the executive committee of the International Social Science Council (ISSC), an office he took with the utmost seriousness and 
which he hoped to use to promote both greater cross-disciplinary organizational contact and further integration of social scientists in Asia and Africa. Having become fluent in four or five languages, he thrived in the atmosphere of international scientific administration and had a unique capacity for bringing both vision and practicality to a wide range of issues and projects. His work on the international arena was so very far from being completed.

With such a high profile as an administrator in recent years, it's easy to loose sight of Franco's considerable production as a social scientist. He was author or coauthor of 10 major works and more than 60 articles and high-profile papers. More important than the volume of his production, however, was the growing range of his interests and research involvements. Long recognized in an international capacity in the area of local governance, he had, over the past five years or so, expanded his interests to cover both the politics of divided countries and issues of sustainable development in a North-South context. At the time of his death, he was working with colleagues from India and Eastern Europe on comparative projects along very different dimensions, having returned to research again with full vigour after his prolonged period of initial illness.

Francesco Kjellberg was what they would have called in the American West "a man to be reckoned with." He was possessed of a complex personality: a powerful and assertive intelligence combined with deep reservoirs of charm and wit. He had an enormous sensitivity for injustice in any form, and was always willing to take the side of the underdog. $\mathrm{He}$ also had a very strong "existentialist" streak, constantly willing to explore the personal implications of his own positions, and ever on the alert for "bad faith." He was also both exceptionally loyal and exceptionally open in whatever he undertook. In short, he was a man of integrity, a "traditionalist" in the very best sense of the word.

With Franco's death, IPSA and political scientists around the world have lost a true friend and champion of the discipline. Our thoughts and deepest sympathies go out to his immediate family who have lost such a vital part of their lives at a much too early date. He was a man who made a difference, and he will long be remembered and honoured by colleagues and friends everywhere.

\section{William M. Lafferty \\ University of Oslo}

\section{William Webster Lammers}

It is with great sadness that we report the death of William Webster Lammers on October 7, 1997. He died at the USC/Norris Cancer Hospital in Los Angeles at the age of 60 .

Bill was born in Waseca, Minnesota, and he received his A.B. in history in 1959 and his M.A. and Ph.D. in political science in 1960 and 1966, respectively, from the University of Minnesota. He was initiated into Phi Beta Kappa during his junior year in college, and he later served as faculty president of Phi Beta Kappa for two years. He joined the department of political science at the University of Southern California as an instructor in 1964 and was appointed an assistant professor in 1966. He was promoted to associate professor in 1970 and to full professor in 1984. He served on the faculty senate and chaired the division of social sciences promotion and tenure committee. He made frequent television, radio, and speaking appearances, particularly during election years, and he served as a consultant on social security issues for several members of Congress.

Bill was acting chair from 19711973 and again during the spring semester of 1986. As we all know, it takes a leader, a conciliator, a compromiser, a strong person, to head a diverse group of independentminded academics. These are qualities he had in abundance, along with an integrity and genuineness that shone through his persona. Moreover, he was always reliable. You could always count on Bill. He sat on a number of department and university committees, and he always came well prepared with notes, and did not "wing it" as many of our colleagues have done.

Bill's research focused on Ameri- can politics and public policy. $\mathrm{He}$ was the author of two books on the American presidency and three books on aging policy. His papers consistently appeared in the top political science journals, including Presidential Studies Quarterly, Political Science Quarterly, Policy Studies Review, Canadian Journal of Political Science, Publius, and American Journal of Political Science. He presented papers at the annual meetings of the American Political Science Association and the Western Political Science Association on a regular basis.

Bill developed a massive data base on the professional background and actions of individual presidents to facilitate his research on executive behavior and policy formation. Completed shortly before his death, Comparing Presidents: Leadership and Domestic Policy (CQ Press, forthcoming) analyzes the leadership abilities and styles of presidents from FDR through Clinton. His article in Political Science Quarterly, "Presidential Press Conference Schedules: Who Hides, and When," provides an extremely perceptive and insightful study of when presidents choose to hold news conferences and how those decisions affect public opinion. He also collaborated with Joseph Nyomarkay on a major study of career patterns of cabinet officials in Austria, Canada, France, Germany, and Great Britain.

Bill also wrote extensively about aging policy in the United States. He analyzed a wide variety of government policies toward older adults in Public Policy and the Aging, published by CQ Press. "The aging are destined to become a larger and more influential segment of American society," he wrote in his 1983 book. "The falling birthrate beginning in the early 1960 s, coupled with increases in life expectancy, makes this demographic shift inevitable. The number of older persons with the personal resources and political skills needed to participate in the political process is growing, and elected officials are becoming increasingly sensitive to their voting strength. The mixture of policies that will emerge in response to those political and demographic changes will have important implications not only for present and future aged popula- 